\title{
Cholecystocolonic fistula: a rare intraluminal cause of large bowel obstruction
}

\author{
Amit Kumar Reddy, Elizabeth R Dennett
}

Department of Surgery and Anaesthesia, University of Otago Wellington, Wellington, New Zealand

\section{Correspondence to} Dr Amit Kumar Reddy, amit_reddy1@hotmail.com

Accepted 17 August 2016
To cite: Reddy AK, Dennett ER. BMJ Case Rep Published online: [please include Day Month Year] doi:10.1136/bcr-2016217141

\section{DESCRIPTION}

An 87-year-old man presented acutely to our institution with a clinical diagnosis of large bowel obstruction following treatment by his general practitioner for diarrhoea. His background was of conservative treatment of cholecystitis 3 years previously. A CT scan suggested a large bowel obstruction at the level of the sigmoid colon with an intraluminal opacity identified at that point. Air was present within the biliary system and a connection could be observed between the gallbladder and the hepatic flexure. A diagnosis of a cholecystocolonic fistula was made. The patient proceeded to laparotomy where a stercoral-type perforation was identified in the sigmoid colon due to the obstructing intraluminal object (figure 1). A densely thickened gallbladder was identified and a cholecystocolonic fistula was confirmed. A partial cholecystectomy was performed with a subtotal colectomy and formation of an end ileostomy.

Cholecystoenteric fistulae are an uncommon complication of gallstone disease. The most common type of fistula is between the gallbladder and duodenum; however, a cholecystocolonic fistula represents the second most common abnormal connection. ${ }^{12}$ The underlying pathophysiology is related to chronic inflammation due to gallstones; however, other mechanisms have been described including gallbladder malignancy, previous gastric surgery, previous cholecystostomy and penetrating abdominal wounds. ${ }^{1}$

These fistulae are most commonly asymptomatic and are often identified incidentally during laparoscopic gallbladder surgery. When they do present with symptoms the most commonly described is diarrhoea. ${ }^{1}$ The diarrhoea experienced is related to malabsorption, with bile acids bypassing enterohepatic recirculation in the terminal ileum and having a laxative effect in the colon. Presentation may also be with large bowel obstruction. Most commonly the stone is obstructed in the sigmoid colon, these stones tend to be $>2.5 \mathrm{~cm}$ in diameter with smaller stones presumed to pass through to colon. ${ }^{2} 3$

Plain X-ray may suggest the diagnosis with pneumobilia and large bowel obstruction with an opacified gallstone seen in the colon. CT imaging was diagnostic in our case and is a useful investigation in these patients.

In treating an acute complication of a cholecystocolonic fistula several methods have been described including surgical and endoscopic options. ${ }^{3}$ Surgical treatment may be divided into management of the direct complication as well as the underlying cholecystocolonic fistula. Large bowel obstruction may be treated with enterolithotomy, formation of a colostomy or resection with anastomosis depending on the state of the colon. The

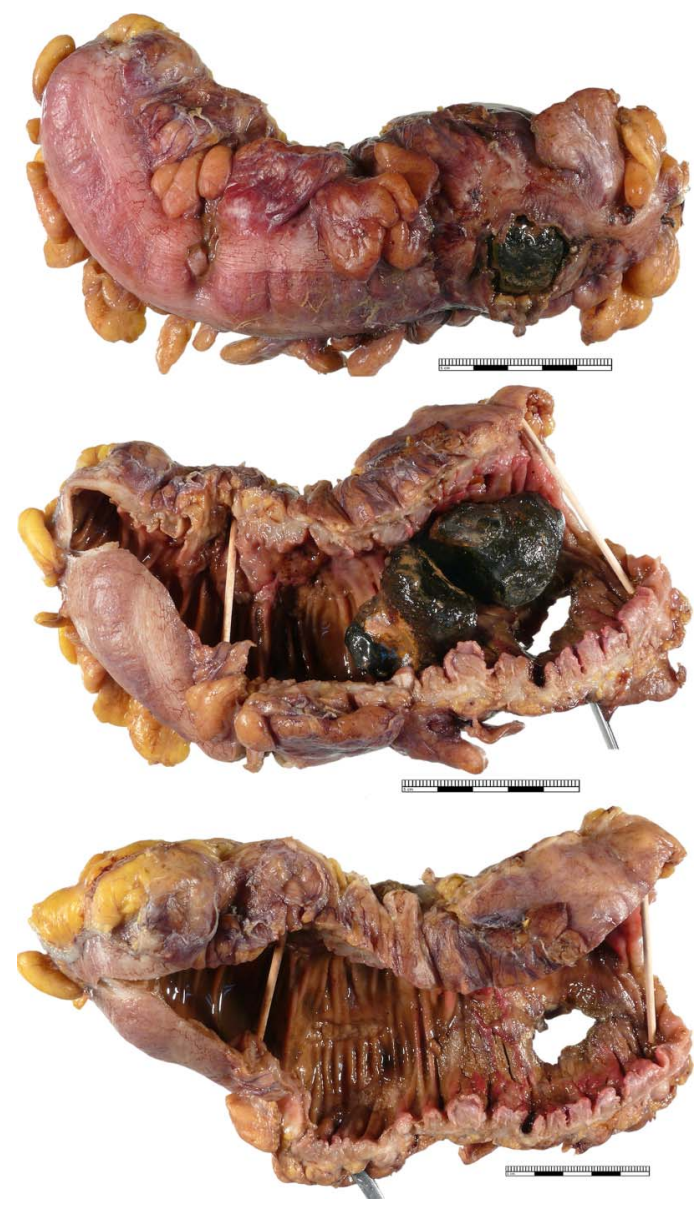

Figure 1 Photograph of the resected sigmoid colon specimen with impacted gallstone and site of local perforation.

\section{Learning points}

- Cholecystocolonic fistula is a rare condition; the presentation may be vague but diarrhoea is the most common symptom.

- Gallstone impaction in the sigmoid colon may present initially with diarrhoea with large bowel obstruction.

- CT imaging is a useful investigation to diagnose preoperatively with diagnostic features of large bowel obstruction, an intraluminal mass and air within the biliary system.

management of the underlying cholecystocolonic fistula remains an area of debate. Case reports exist for successful cholecystectomy at the emergency operation, as an interval procedure, but some have 


\section{Images in...}

avoided cholecystectomy altogether. ${ }^{1}$ No consensus exists with regards to optimal treatment. The decision should be dictated by the condition of the patient and the experience of the surgeon.

Acknowledgements The authors would like to acknowledge Louise Goossens Medical photographer for taking the clinical photographs.

Contributors AKR assisted with the surgical management of this patient, performed the literature review and wrote the manuscript. ERD provided primary care for the patient and proof read the manuscript.

Competing interests None declared.
Patient consent Obtained.

Provenance and peer review Not commissioned; externally peer reviewed.

\section{REFERENCES}

1 Costi R, Randone B, Violi V, et al. Cholecystocolonic fistula: facts and myths. A review of the 231 published cases. J Hepatobiliary Pancreat Surg 2009;16:8-18.

2 Glenn F, Reed C, Grafe WR. Biliary enteric fistula. Surg Gynaecol Obstet 1981;153:527-31.

3 Milsom JW, MacKeigan JM. Gallstone obstruction of the colon. Report of two cases and review of management. Dis Colon Rectum 1985;28:367-70.

Copyright 2016 BMJ Publishing Group. All rights reserved. For permission to reuse any of this content visit http://group.bmj.com/group/rights-licensing/permissions.

BMJ Case Report Fellows may re-use this article for personal use and teaching without any further permission.

Become a Fellow of BMJ Case Reports today and you can:

- Submit as many cases as you like

- Enjoy fast sympathetic peer review and rapid publication of accepted articles

- Access all the published articles

- Re-use any of the published material for personal use and teaching without further permission

For information on Institutional Fellowships contact consortiasales@bmjgroup.com

Visit casereports.bmj.com for more articles like this and to become a Fellow 